\title{
KEGIATAN USAB ABUR DALAM MENGEMBANGKAN KREATIVITAS ANAK USIA DINI
}

\author{
Veryawan $^{1}$, Siti Habsari Pratiwi ${ }^{2}$, Ubaidillah ${ }^{3}$ \\ ${ }^{1,2}$ Institut Agama Islam Negeri Langsa, Indonesia \\ ${ }^{3}$ Universitas Saburai, Indonesia \\ veryawan@iainlangsa.ac.id
}

\begin{abstract}
The low level of creativity of group B III TK Kartika Padangsidimpuan children was the problem of this research. Whereas the ability of creativity is an ability that must be developed from a child so that his / her imagination and personality will increase according to the level of development. However, in reality creativity is still considered less important by some parents and even adults around children. Rub away activity is one option to be able to develop creativity in early childhood. This type of research is a classroom action research which has stages of planning, implementation, observation and reflection. The subjects of this study were 16 children of group B III TK Kartika Padangsidimpuan consisting of 4 girls and 12 boys using instruments, namely observation sheets and data analysis, which used qualitative analysis techniques which can be seen from children's creativity and quantitative data. which has been calculated by the formula. Research results obtained in children's creativity have increased. Before the action was taken, the level of children's creativity was still very low, after the first cycle research was carried out it gained 44\% and in the second cycle it increased to $80 \%$. After conducting research starting from pre-cycle, cycle I and cycle II it was concluded that the creativity of group B III TK Kartika Padangsidimpuan children had increased through rub away activities.
\end{abstract}

Keywords: rub away, creativity, early childhood

\begin{abstract}
Abstrak
Rendahnya tingkat kreativitas anak kelompok B III TK Kartika Padangsidimpuan merupakan masalah dari dilakukannya penelitian ini. Padahal kemampuan kreativitas merupakan suatu kemampuan yang harus dikembangkan dari seorang anak agar daya imajinasi dan kepribadiannya meningkat sesuai dengan tingkat perkembangannya. Namun kenyataannya kreativitas masih dianggap kurang penting oleh sebagian orang tua bahkan orang dewasa disekitar anak. Kegiatan usab abur merupakan salah satu pilihan untuk dapat mengembangkan kreativitas anak usia dini. Jenis penelitian ini adalah penelitian tindakan kelas yang memiliki tahapan perencanaan, pelaksanaan, observasi dan refleksi. Subjek penelitian ini adalah anak kelompok B III TK Kartika Padangsidimpuan yang berjumlah 16 orang yang terdiri dari 4 perempuan dan 12 laki-laki dengan menggunakan instrumen yaitu lembar observasi dan analisis data, yang digunakan yaitu teknik analisis kualitatif yang dapat dilihat dari kreativitas anak dan data kuantitatif yang telah dihitung dengan rumus. Hasil penelitian yang diperoleh dalam kreativitas anak mengalami peningkatan. Sebelum dilakukan tindakan, tingkat kreativitas anak masih sangat rendah, setelah dilakukan penelitian kelas siklus I memperoleh $44 \%$ dan pada siklus II meningkat menjadi $80 \%$. Setelah dilakukan penelitian mulai dari pra siklus, siklus I dan siklus II disimpulkan bahwa kreativitas anak kelompok B III TK Kartika Padangsidimpuan mengalami peningkatan melalui kegiatan usab abur.
\end{abstract}

Kata Kunci: usab abur, kreativitas, anak usia dini 


\section{PENDAHULUAN}

Usia dini merupakan masa pertumbuhan dan perkembangan seorang anak yang memerlukan bantuan dari orang dewasa yang ada dilingkungannya. Bantuan yang dapat membantu dalam tumbuh kembang anak. Dapat berupa rangsangan untuk pertumbuhan jasmani dan keterampilan anak. Rangsangan ini seperti memberikan kegiatan-kegiatan yang dapat membantu mengembangkan berbagai potensi yang dimiliki anak yang meliputi nilai-nilai agama, moral, sosial emosional, kemandirian, kognitif, bahasa, fisik motorik dan seni. Pendidik merupakan sebagai wadah dalam membantu anak dalam lingkungan sekolah juga mempunyai tanggung jawab yang besar dalam membantu tumbuh kembang anak, baik jasmani maupun keterampilan anak. Sebagai orang tua atau pendidik perlu mengembangkan serta memberikan berbagai stimulasi positif agar anak dapat menjadi kreatif (Putro, 2016).

Memaknai pengertian kreativitas banyak pendapat mengatakan bahwa kreativitas adalah kemampuan seseorang dengan imajinasinya dalam menciptakan sesuatu dan memecahkan masalah yang dimiliki seseorang (Anggraini \& Kuswanto, 2019; F. Astuti, 2013). Kreativitas akan muncul pada anak yang memiliki rasa ingin tahu, motivasi yang tinggi dan imajinatif. Anak yang kreatif akan menemukan sendiri pemecahan masalah yang dihadapinya dan selalu bersikap terbuka pada hal-hal baru, suka mengekspresikan diri dan bersikap natural tanpa dibuat-buat. Anak kreatif adalah anak yang dapat menciptakan suatu karya yang baru atau hasil dari berbagai cara sehingga dapat memodifikasi menjadi bentuk baru (Adhani et al., 2017). Kreatifitas merupakan kemampuan untuk memberikan gagasan-gagasan baru yang dapat diterapkan dalam pemecahan masalah atau sebagai kemampuan untuk melihat hubunganhubungan baru antara unsur-unsur yang telah ada sebelumnya (Jumilah et al., 2018).

Menurut Setyabudi (Debeturu \& Wijayaningsih, 2019) bahwa penggunaan cara yang baru dan lebih baik serta dapat merealisasikan hasil dari ide-ide yang bermanfaat dari proses penyatuan berbagai bidang pengetahuan yang berlainan merupakan pengertian dari kreativitas. Munandar (Nurhayati, 2012) menerangkan bahwa kreativitas adalah kemampuan untuk dapat memberikan suatu ide gagasan baru lalu dapat menerapkannya dalam pemecahan masalah. Kreatifitas anak usia dini adalah dengan memberi kebebasan kepada anak dalam menyampaikan dan menuangkan isi pikirannya. (Sukamti, 2010:53) juga mengungkapkan bahwa kreativitas merupakan kemampuan melahirkan sesuatu yang bermakna dan bermanfaat yang diciptakan atau dikombinasi berdasarkan pada unsur yang telah ada sebelumnya. 
Supriyadi (Priyanto, 2014) juga menjelaskan kreativitas dapat menciptakan sesuatu yang baru, baik berupa ide gagasan yang berbeda berupa karya nyata dari yang telah ada sebelumnya.

Menurut Conny R. Semiawan, 1999 (Anhusadar, 2016) bahwa kreativitas juga merupakan membawa sesuatu yang baru ke dalam kehidupan dengan kemampuan yang dimilikinya. Menciptakan suatu proses belajar mengajar yang baru juga dapat disebut hasil dari kreativitas seperti: kreativitas adalah kemampuan untuk membuat kombinasi-kombinasi atau melihat hubungan-hubungan baru antara unsur, variable dan data yang sudah ada sebelumnya dan kreativitas merupakan gagasan maupun karya nyata yang relative berbeda yang dihasilkan oleh seseorang yang memiliki kemampuan.

Terdapat banyak arti kreativitas diantaranya yang sering digunakan Hurlock, 1995 (H. P. Astuti, 2013) yaitu kreativitas menekankan pembuatan sesuatu yang baru dan berbeda, kreativitas adalah hasil kreasi sesuatu yang baru dan orisinil secara kebetulan, kreativitas adalah apa saja yang diciptakan selalu baru dan berbeda dari yang telah ada dan karenanya unik, kreativitas merupakan menghasilkan sesuatu yang baru, berbeda, dan orisinal dari suatu proses mental, kreativitas adalah kejeniusan yang dimiliki pada seseorang dan tidak ada hubungannya dengan belajar atau lingkungan, kreativitas umumnya dianggap sinonim dengan imajinasi dan fantasi dan karenanya merupakan bentuk permainan mental, kreativitas merupakan suatu kombinasi baru antara data dan informasi atau unsur yang ada, kreativitas adalah banyak menemukan kemungkinan jawaban pada suatu masalah, ketepatgunaan, dan keragaman jawaban. Kreativitas anak terdiri atas beberapa karakateristik, yaitu: mementingkan proses daripada hasil, memiliki proses tujuan, dapat menciptakan sesuatu hasil yang baru, dan salah satu sarana untuk berpikir (Yulida \& Veryawan, 2018).

Keberhasilan seseorang dalam mengerjakan dan menyelesaikan suatu tugas juga harus memiliki kemampuan dan kreativitas yang tinggi. Lestari (Peny Husna et al., 2017) menyatakan bahwa pengembangan kepribadian anak harus sejalan dengan pengembangan kreativitasnya. Jika anak mengalami perkembangan kepribadian yang sehat, mandiri, percaya diri dan produktif maka kreativitas anak juga akan dapat berkembang dengan baik. Dan sebaliknya, jika anak mengalami pertumbuhan kepribadian yang minder, pesimis, tidak memiliki keberanian dan kurang aktif maka kreativitas anak juga tidak akan berkembang dengan baik. Isenberg \& Jalongo, 1993 (Miranda, 2016) mengungkapkan bahwa kemampuan membentuk suatu imaji mental dari berbagai konsep merupakan kreativitas pada anak usia dini. 
Untuk mempertahankan daya kreatif dan keterampilan yang dimiliki anak, guru harus memperhatikan sifat natural anak, dimana sifat ini sangat menunjang dalam tumbuhnya kreatif anak. Sifat-sifat ini harus dipupuk dan dikembangkan oleh guru sebagai pendidik di sekolah dan orangtua di rumah. Guru bisa memberi kesempatan bagi anak dengan mengajak anak bermain didalam dan diluar ruangan. Pengembangan kreativitas pada anak usia dini yaitu usia dari 0 sampai 6 tahun sudah dapat dilatih. Pengembangan kreativitas anak dapat dikembangkan melalui permainan. Hal ini sejalan dengan artikel (R. Astuti \& Aziz, 2019) bahwa kreativitas bukan merupakan hal yang asing bagi pembelajaran anak usia dini karena setiap hal yang di lakukan anak merupakan kreativitas anak secara alami. Anak kreatif memuaskan rasa keingintahuannya melalui berbagai cara seperti bereksplorasi, bereksperimen dan banyak mengajukan pertanyaan kepada orang lain (Hardiyanti et al., 2018). Sangat banyak jenis permainan yang dapat merangsang perkembangan kreativitas anak seperti: playdough, melukis dengan jari (usap abur), mencetak, menjahit, menggambar, mewarnai, kolase dan lain sebagainya.

Kegiatan mewarnai dan menggambar suatu gambar dengan rapi, membuat gambar dengan tehnik mozaik dengan memakai berbagai bentuk dan membuat bentuk dari media plastisin, lempung dan lain-lain tertuang dalam indikator dari kemampuan dasar fisik motorik halus dan seni pada Kurikulum Standar Kompetensi Pendidikan Anak Usia Dini. Sejalan pendapat Sujiono, 2010 (Fitri \& Hazizah, 2019) dalam sentra seni dan kreativitas anak dapat melatih keterampilan tangan dalam mengembangkan kemampuan motorik halusnya dengan optimal seperti melipat, menggunting, merekat, prakarya, melukis dan pertukangan. Dengan banyak melalukan kegiatan seni maka kreativitas anak juga akan berkembang. Warsita 2008 (Wahyuti et al., 2017) menyatakan bahwa suatu kegiatan ada langkah-langkah ataupun prosedur yang telah disiapkan dalam menggunakan bahan, alat, lingkungan dan orang untuk menyampaikan pesan. Usap abur adalah salah satu kegiatan menggambar yang menggunakan kekuatan jari-jari untuk membentuk sebuah objek. Pengembangan motorik halus melalui proses pencampuran warna dengan mengoreskan warna pada pola yang tersedia serta dalam pelaksanaan kreatifnya lebih mengutamakan nilai kepekaan, estetika serta keterampilan motorik halus sehingga seorang anak bisa mengekspresikan atau menuangkan sesuatu yang ada dalam pikirannya terhadap kegiatan yang dilakukan oleh anak-anak merupakan pengertian dari usab abur (Elmi Susrianti, 2016). 
Menurut Pamadhi dan Sukardi, 2009 (Martinasari et al., 2016) bahwa mewarnai gambar sederhana (usap abur) mengembangkan rasa keindahan melalui sentuhan warna dan keartistikan bentuk merupakan pembinaan yang ditujukan pada keterampilan menggambar. Kegiatan ini dilakukan dengan memberi warna, memilih warna dan menjajarkan warna untuk mendapatkan kemampuan-kemampuan yang berguna bagi perkembangan pendidikan anak (Pamadhi \& Sukardi, 2013). Dibutuhkan ketelitian dan keuletan pada teknik yang tepat digunakan untuk mengembangkan gerak motorik halus anak-anak. Media pembelajaran merupakan komponen yang saling berhubungan dengan komponen lainnya untuk menciptakan situasi belajar yang diharapkan. Proses pembelajaran tidak akan berjalan dengan efektif tanpa adanya suatu media (Zaman \& Hernawan, 2016:3.10). Dengan menggunakan kegiatan usap abur diharapkan akan meningkatkan minat anak dalam berpartisipasi dalam proses kegiatan pembelajaran.

Hal ini sesuai dengan penelitian sebelumnya pada artikel (Aisyah, 2017) menyimpulkan bahwa dari satu anak tergolong kreatif pada saat sebelum kegiatan bermain warna kemudian dapat meningkat ketika sesudah bermain warna. Ini merupakan hasil analisa data teknik permainan warna dapat meningkatkan kreativitas anak setelah mereka diberi kegiatan bermainan warna. Kesimpulan artikel (Anggia \& Nopriansyah, 2018) bahwa melalui permainan warna dengan menggunakan media benang dapat meningkatkan kreativitas anak usia dini. Artikel (Larasati et al., 2016) menyimpulkan bahwa adanya hasil yang cukup signifikan bahwa kreativitas anak terhadap kegiatan mewarnai dengan menggunakan metode demonstrasi dengan hasil perhitungan t-test $\mathrm{t}$ hitung $=-21,73 \geq(5 \%=2,16$ dan $1 \%=3,01$. Dan artikel (Wibowo \& Suyadi, 2020) bahwa evaluasi yang diperoleh adalah anak antusias dalam mengaplikasikan kreativitas seni menggunakan cat warna dengan adanya suatu hasil karya yang bernilai estetik untuk dipandang dan digunakan sebagai alat bermain.

Berdasarkan hasil observasi dilapangan pada semester II pada kelompok B III anak-anak mengalami keterlambatan dalam kegiatan usap abur, terutama dalam kreativitas anak. Hal ini terlihat dari kurang terampilnya anak dalam pengembangan kreativitas menggunakan media kertas dalam kegiatan pembelajaran, khususnya dalam kegiatan usap abur. Didalam kegiatan usap abur anak melukis dengan jari, anak belum terampil, kaku dan merasa asing. Hal ini dapat dilihat pada saat anak kelompok B III diberi kegiatan menggambar dengan tema tanaman subsub tema sayuran anak hanya membentuk lingkaran, anak meniru gambar teman sebangkunya, 
mereka belum bisa berkreasi sendiri. Dari 16 orang anak hanya 5 orang anak yang menggambar berbeda dengan teman-temannya. Kegiatan lain juga menunjukkan hal yang demikian. Ketika anak-anak kelompok B III diberikan playdough untuk membentuk secara bebas. Anak-anak hanya membuat sesuai dengan contoh yang ada saja tanpa menambah bentuk lain, terkadang anak sering mengatakan kata "tidak bisa bu" saat diminta untuk membuat bentuk lain.

Pada kegiatan pengembangan keterampilan anak di sekolah pendidik sering mengalami kesulitan sehingga hasil yang diharapkan tidak maksimal. Penyebabnya antara lain, pengelolaan kelas kurang dikuasai, penggunaan metode yang kurang tepat dan pendidik yang kurang kreatif. Didalam menumbuh kembangkan kreativitas yang miliki anak untuk meningkatkan keterampialan motorik halus guru berupaya semaksimal mungkin dengan memperkenalkan dan melatih gerak motorik kasar atau halus, mengontrol gerakan tubuh, meningkatkan keterampilan tubuh dan hidup sehat sehingga mewujudkan anak yang terampil dan mempunyai jasmani yang kuat.

Namun kenyataannya dapat dilihat bahwa saat ini dilapangan bahwa kreativitas anak kelompok B masih tergolong rendah. Hal ini disebabkan oleh proses belajar mengajar yang monoton, kurangnya interaksi guru dengan anak, pendidik lebih sering menggunakan model pembelajaran yang kurang menarik dan keterampilan jari-jari anak yang kaku. Untuk mengantisipasi masalah tersebut, dalam proses belajar mengajar pendidik harus menggunakan model pembelajaran yang sesuai yaitu melalui permainan usap abur agar kreativitas yang dimiliki anak meningkat. Menurut (Susanto, 2012) bahwa kreativitas anak akan berkembang melalui pembelajaran dengan bermain atau belajar sambil bermain. Karena melalui bermain kognitif anak akan berkembang, sehingga anak akan dapat berpikir kreatif untuk memasuki lingkungannya, anak juga akan mampu menciptakan sesuatu karya yang unik dank has sesuai dengan pemikirannya. Bermain mendukung tumbuhnya pikiran kreatif karena dalam bermain anak memilih sendiri kegiatan yang mereka sukai, belajar membuat identifikasi tentang banyak hal, belajar menikmati proses sebuah kegiatan, belajar mengontrol diri mereka sendiri dan belajar mengenali makna sosialisasi dan kederadaan diri di antara teman sebaya (Musfiroh \& Tatminingsih, 2015).

Tujuan dari penelitian ini adalah untuk meningkatkan kreativitas anak melalui kegiatan usap abur, disamping dapat meningkatkan kreativitas anak, hal ini juga dapat menumbuhkan daya tarik dan minat anak dalam proses belajar sehingga menghasilkan hasil belajar yang 
maksimal. Manfaat yang diperoleh dari penulisan penelitian ini, yaitu: manfaat teoritis mendapatkan teori baru dan sumbangan keilmuan tentang peningkatan kreativitas anak melalui kegiatan usap abur, sehingga dapat dijadikan dasar penelitian selanjutnya, manfaat praktis anak dapat meningkatkan kreativitas anak melalui bermain usap abur dan anak lebih termotivasi dalam melakukan kegiatan usap abur. Guru dapat digunakan sebagai informasi untuk memperbaiki pembelajaran agar guru dapat berkembang secara profesional, kreatif dan inovatif. Sekolah memberikan pengaruh baik terhadap kemajuan sekolah, baik dari peningkatan keterampilan profesional guru dan perbaikan pada proses pembelajaran di sekolah.

\section{METODE PENELITIAN}

Pada TK Kartika Padangsidimpuan kelompok B III TP. 2018/2019 tempat dilakukannya penelitian ini. Penelitian ini terdiri dari 2 siklus, siklus I dimulai dari tanggal 22 Oktober s/d 26 Oktober 2018, siklus II dimulai dari tanggal 29 Oktober s/d 02 November 2018. Subjek penelitian ini adalah anak didik TK Kartika Padangsidinpuan pada kelompok B III yang berjumlah 16 orang yang terdiri dari 4 perempuan dan 12 laki-laki dengan tema tanaman. Sedangkan objek dari penelitian ini adalah kegiatan anak mengetahui sejauh mana peningkatan kreativitas peserta didik melalui kegiatan usap abur. Dalam penelitian ini dikemas dalam bentuk penelitian tindakan kelas dan metode ini digunakan terutama yang diteliti bersumber dari masalah yang timbul sehari-hari didalam kelas dan penelitian tindakan kelas adalah penelitian praktis yang dapat memperbaiki pembelajaran kelas. Penelitian ini menggunakan metode rancangan (Arikunto, 2015), dengan dua siklus. Dengan pelaksanaan perbaikan mengikuti pola perencanaan, pelaksanaan, pengamatan dan refleksi. Penelitian ini menggunakan teknik observasi, wawancara, dokumentasi dan tes dalam proses pengumpulan data. Dalam menginterpretasi hasil analisis yang dilakukan pada saat proses kegiatan usap abur berlangsung, peneliti menggunakan analisa persentase untuk memperoleh hasil tentang upaya meningkatkan kreativitas anak melalui kegiatan usap abur dan tes analisa menggunakan rata-rata anak dan kriteria ketuntasan belajar anak. Dalam penelitian dianggap berhasil jika hasil yang dicapi anak telah mencapai $80 \%$ dalam peningkatan kreativitas anak dalam melakukan kegiatan usap abur. 


\section{HASIL PENELITIAN DAN PEMBAHASAN}

Setelah melakukan proses kegiatan siklus I maka saya melakukan refleksi untuk perbaikan kegiatan pembelajaran. Dari hasil kegiatan yang dilakukan anak dari 15 orang anak hanya 4 orang anak yang memperoleh predikat BSB (Berkembang Sangat Baik), 3 orang anak memperoleh predikat BSH (Berkembang Sesuai Harapan), 2 orang anak memperoleh predikat MB (Mulai Berkembang) dan 6 orang anak memperoleh predikat BB (Belum Berkembang), hasil ini diasumsikan karena penjelasan yang saya sampaikan kurang dipahami anak, metode dan media yang diberikan tidak tepat, saya kurang memotivasi anak dalam melakukan kegiatan yang dilakukan serta penguatan dan umpan balik terhadap hasil kegiatan anak kurang memotivasi anak. Pada penelitian siklus I ada beberapa temuan yang menjadi perhatian penelitian, guru dan teman sejawat yaitu: proses kegiatan belajar berlangsung menyenangkan, meski masih banyak kekurangan, hanya 4 orang anak yang dapat melakukan kegiatan sesuai sesuai indikator yang telah ditentukan, 6 orang anak yang belum dapat mengikuti kegiatan dengan baik, hal ini dapat dilihat dari tiga aspek penelitian yang belum dipenuhi serta anak tidak fokus dan merasa bosan karena media dan metode kegiatan kurang menarik. Hal ini dapat digambarkan dalam tabel di bawah ini:

Tabel Hasil Presentase Peniaian Siklus I

\begin{tabular}{llcccc}
\hline \multirow{2}{*}{ No } & \multicolumn{1}{c}{ Aspek yang dinilai } & \multicolumn{4}{c}{ Jumlah Anak } \\
\cline { 2 - 5 } & & BB & MB & BSH & BSB \\
\hline 1 & Dapat mendengar penjelasan & 6 & 2 & 3 & 4 \\
& $\begin{array}{l}\text { tentang kegiatan usap abur } \\
\text { Presentase }\end{array}$ & $40 \%$ & $13,3 \%$ & $20 \%$ & $26,7 \%$ \\
& Anak dapat melakukan kegiatan & 6 & 2 & 3 & 4 \\
& $\begin{array}{l}\text { usap abur } \\
\text { Presentase }\end{array}$ & $40 \%$ & $13,3 \%$ & $20 \%$ & $26,7 \%$ \\
& $\begin{array}{l}\text { Anak mampu berimajinasi dan } \\
\text { berkreasi }\end{array}$ & 6 & 2 & 3 & 4 \\
Presentase & $40 \%$ & $13,3 \%$ & $20 \%$ & $26,7 \%$ \\
\hline
\end{tabular}

Keterangan:

BB : Belum Berkembang

BSH : Berkembang Sesuai Harapan

MB : Mulai Berkembang

BSB : Berkembang Sangat Baik 


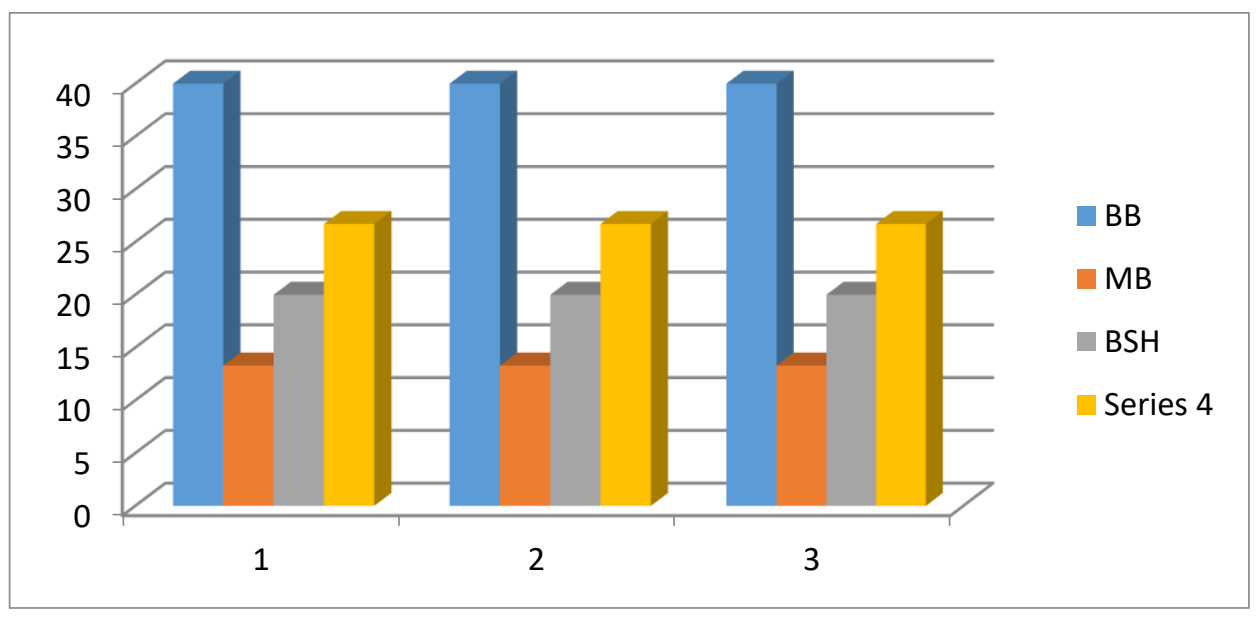

Gambar Diagram Batang Hasil Penilaian Siklus I

Berdasarkan data dari hasil diagram diatas, terlihat bahwa kemampuan anak yang dapat melakukan kegiatan usap abur dan mampu berimajinasi dan berkreasi yang mendapat predikat Berkembang Sangat Baik (BSB) yaitu 4 orang dengan persentase 26,7\%, yang mendapat Berkembang Sesuai Harapan (BSH) yaitu 3 orang dengan persentase 20\%, yang mendapat predikat Mulai Berkembang (MB) yaitu 2 orang dengan persentas 13,3\% dan yang mendapat predikat Belum Berkembang (BB) yaitu 6 orang dengan persentase $40 \%$ dengan demikian tingkat keberhasilan pelaksanaan kegiatan usap abur dengan menunjukkan tingkat keberhasilan dalam melakukan kegiatan usap abur guna meningkatkan kreativitas anak masih terbilang rendah atau belum mencapai hasil maksimal terhadap tingkat pengembangan yang diharapkan.

Berdasarkan hasil data pada siklus I saya melakukan refleksi kegiatan pembelajaran, untuk itu dalam melaksanakan pembelajaran pada kegiatan siklus II, saya mengadakan perbaikan pembelajaran pada siklus II dengan cara sebagai berikut: penjelasan terhadap kegiatan pembelajaran sebaiknya menggunakan bahasa yang dimengerti anak, perorganisasian kelas agar lebih dikondisikan sehingga dapat melakkan kegiatan lebih baik dan media pembelajaran yang digunakan dapat menarik perhatian dan memotivasi anak. Dalam pelaksanaan penelitian siklus II ada beberapa hasil dan temuan sebagai berikut: proses kegiatan belajar berlangsung baik dan menyenangkan, ada 14 orang anak dapat melakukan kegiatan sesuai indikator yang telah ditentukan, hanya 2 orang anak yang belum dapat melakukan kegiatan sesuai indikator yang telah ditentukan dan anak sangat tertarik dan fokus dalam pelaksanaan kegiatan bahkan anak mulai mencoba membaca permulaan dengan menggunakan media kartu bergambar. Hal ini dapat digambarkan dalam tabel dibawah ini : 
Tabel Hasil Presentase Penilaian Siklus II

\begin{tabular}{llcccc}
\hline \multirow{2}{*}{ No } & \multicolumn{1}{c}{ Aspek yang dinilai } & \multicolumn{4}{c}{ Jumlah Anak } \\
\cline { 3 - 6 } & \multicolumn{1}{c}{ BB } & MB & BSH & BSB \\
\hline 1 & $\begin{array}{l}\text { Dapat mendengar penjelasan tentang } \\
\text { kegiatan Usap Abur }\end{array}$ & 1 & 1 & 2 & 11 \\
& $\begin{array}{l}\text { Presentase } \\
2\end{array}$ & $6,7 \%$ & $6,7 \%$ & $13,3 \%$ & $73,3 \%$ \\
& $\begin{array}{l}\text { Anak dapat melakukan kegiatan usap } \\
\text { abur }\end{array}$ & 1 & 1 & 2 & 11 \\
& $\begin{array}{l}\text { Presentase } \\
\text { Anak mampu berimajinasi dan }\end{array}$ & $6,7 \%$ & $6,7 \%$ & $13,3 \%$ & $73,3 \%$ \\
& $\begin{array}{l}\text { berkreasi } \\
\text { Presentase }\end{array}$ & $6,7 \%$ & $6,7 \%$ & $13,3 \%$ & $73,3 \%$ \\
\hline
\end{tabular}

Keterangan:
BB : Belum Berkembang
BSH : Berkembang Sesuai Harapan
MB : Mulai Berkembang
BSB : Berkembang Sangat Baik

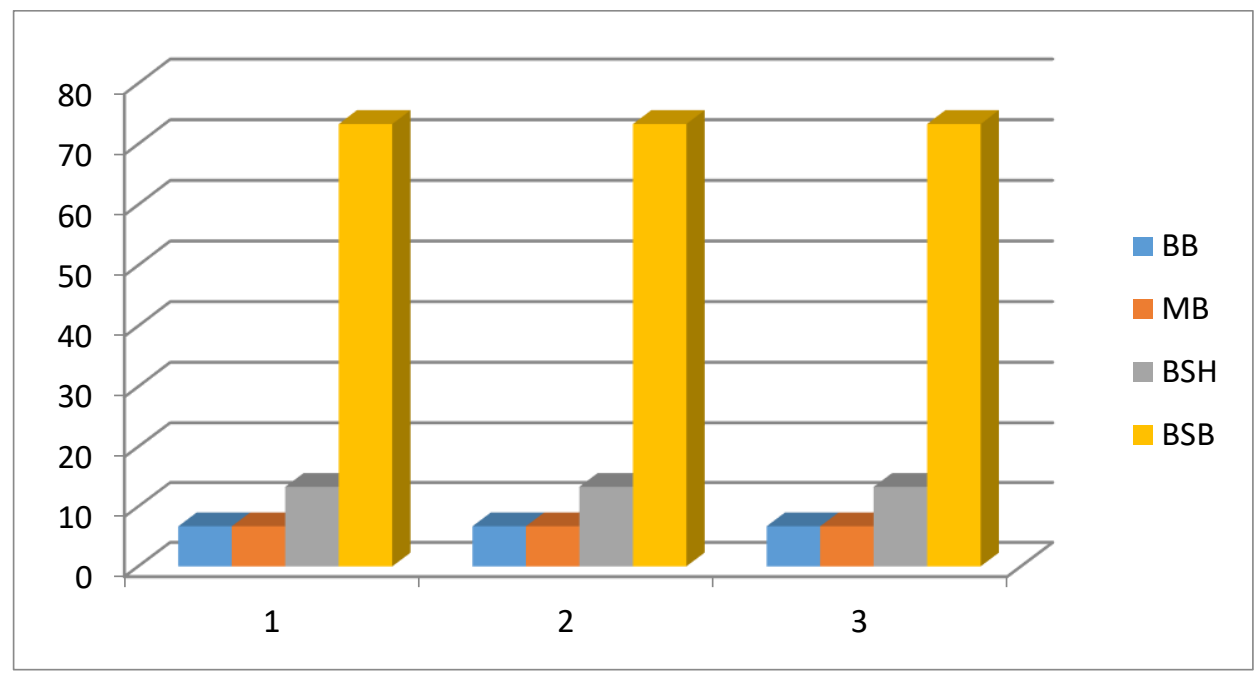

Gambar Diagram Batang Hasil Penilaan Siklus II

Berdasarkan data dari hasil diagram diatas, terlihat bahwa kemampuan anak yang dapat melakukan kegiatan usap abur dan mampu berimajinasi dan berkreasi yang mendapat predikat Berkembang Sangat Baik (BSB) yaitu 11 orang dengan persentase 73,3\%, yang mendapat predikat Berkembang Sesuai Harapan (BSH) yaitu 2 orang dengan persentase 13,3\%, yang 
mendapat predikat Mulai Berkembang (MB) yaitu 1 orang dengan persentas $6,7 \%$ dan yang mendapat predikat Belum Berkembang (BB) yaitu 1 orang dengan persentase 6,7\%. Grafik di atas menunjukkan bahwa pelaksanaan kegiatan usap abur pada siklus II menunjukkan pencapaian yang sangat baik dengan tingkat perkembangan sesuai harapan yaitu $80 \%$. Dengan demikian, melalui kegiatan usap abur dapat meningkatkan kreativitas anak di kelompok B TK Kartika Padangsidimpuan semester I tahun ajaran 2018-2019 sehingga perbaikan kegiatan berhenti sampai pada siklus II.

\section{SIMPULAN DAN SARAN}

Pelaksanaan penelitian ini meningkatkan kreativitas anak melalui kegiatan usap abur telah terlaksana sebanyak dua siklus dengan waktu yang sudah dijadwalkan. Materi dan media pembelajaran serta pelaksanaan yang sudah sesuai dan hasilnya sudah diperoleh yaitu cukup memuaskan. Dari hasil penelitian yang dilakukan terhadap 15 orang anak yang mendapat predikat Berkembang Sangat Baik (BSB) sebanyak 11 orang anak dengan persentase 73,3\%, anak yang mendapat predikat Berkembang Sesuai Harapan (BSH) sebanyak 2 orang anak dengan persentase 13,3\%, anak yang mendapat predikat Mulai Berkembang (MB) sebanyak 1 orang anak dengan persentas 6,7\% dan anak yang mendapat predikat Belum Berkembang (BB) sebanyak 1 orang anak dengan persentase $6,7 \%$. Dari data di atas terlihat bahwa kegiatan usap abur yang dilaksanakan pada siklus II menunjukkan pencapaian hasil yang sangat baik dengan tingkat perkembangan sesuai harapan yaitu 80\%. Dengan perolehan hasil dari kedua siklus ini, maka dapatlah kita ambil kesimpulan bahwa terjadi peningkatan kreativitas anak melalui kegiatan usap abur anak didik usia dini di TK Kartika Padangsidimpuan, media pembelajaran yang digunakan telah dapat menarik perhatian serta motivasi anak didik, pemanfaatan waktu belajar sudah menjadi lebih efisien dan guru berhasil mengembangkan metode belajar dan media yang baik. Untuk saran dari penelitian ini adalah kreativitas melalui kegiatan usap abur sebaiknya sesering mungkin diberikan pada anak usia dini untuk meningkatkan imajinasi dan kreasi anak dalam berkarya, rasa ketertarikan anak didik usia dini pada permainan warna yang tinggi harus bisa dimanfaatkan dan digabungkan dalam metode pembelajaran dan peran pendidik atau sekolah untuk menyediakan media pembelajaran dituntut agar lebih inovatif. Hal ini akan membantu pendidik menjadi pengajar yang lebih profesional dan berkemampuan baik dalam mengajar. 


\section{DAFTAR PUSTAKA}

Adhani, D. N., Hanifah, N., \& Hasanah, I. (2017). Meningkatkan Kreativitas Anak Melalui Kegiatan Bermain Warna. Pg-Paud Trunojoyo, 4(1), 64-75. https://doi.org/https://doi.org/10.21107/pgpaudtrunojoyo.v4i1.3569

Aisyah, A. (2017). Permainan Warna Berpengaruh Terhadap Kreativitas Anak Usia Dini. Jurnal Obsesi : Jurnal Pendidikan Anak Usia Dini, 1(2), 118. https://doi.org/10.31004/obsesi.v1i2.23

Anggia, A. R., \& Nopriansyah, U. (2018). Mengembangkan Kreativitas Anak Melalui Permainan Warna Dengan Media Benang pada Anak Usia 5-6 Tahun di Raudhatul Athfal Perwanida I Bandar Lampung. Http://Ejournal.Radenintan.Ac.Id/Index.Php/AlAthfaal/Article/View/3789, 1(2), 1-20. https://doi.org/https://doi.org/10.24042/ajipaud.v1i2.3789

Anggraini, W., \& Kuswanto, C. W. (2019). Teknik Ceklist Sebagai Asesmen Perkembangan Sosial Emosional di RA. Al-Athfaal: Jurnal Ilmiah Pendidikan Anak Usia Dini, 2(2), 61-70. https://doi.org/10.24042/ajipaud.v2i2.5248

Anhusadar, L. O. (2016). Kreativitas Pendidik di Lembaga PAUD. Jurnal Al-Ta'dib, 9(1), 76-93. https://doi.org/10.1017/CBO9781107415324.004

Arikunto, S. (2015). Prosedur Penelitian Suatu Pendekatan Praktek. Jakarta : Rineka Cipta.

Astuti, F. (2013). Menggali dan Mengembangkan Potensi Kreativitas Seni pada Anak Usia Dini. Komposisi: Jurnal Pendidikan Bahasa, Sastra, Dan Seni, 14(1). https://doi.org/10.24036/komposisi.v14i1.3950

Astuti, H. P. (2013). Smart Parenting: Upaya Peningkatan Kemampuan Kognitif Dan Kreativitas Anak Di Kelurahan Banjarjo, Boja, Kendal. Rekayasa, 11(2), 117-126. https://doi.org/10.15294/rekayasa.v11i2.10317

Astuti, R., \& Aziz, T. (2019). Integrasi Pengembangan Kreativitas Anak Usia Dini di TK Kanisius Sorowajan Yogyakarta. Jurnal Obsesi : Jurnal Pendidikan Anak Usia Dini, 3(2), 294. https://doi.org/10.31004/obsesi.v3i2.99

Debeturu, B., \& Wijayaningsih, E. L. (2019). Meningkatkan Kreativitas Anak Usia 5-6 Tahun melalui Media Magic Puffer Ball. Jurnal Obsesi : Jurnal Pendidikan Anak Usia Dini, 3(1), 233. https://doi.org/10.31004/obsesi.v3i1.180

Elmi Susrianti. (2016). Peningkatan Motorik Halus Anak Melalui Kegiatan Usap Abur Di taman Kanak-kanak Pertiwi III Muaro Kalaban. Jurnal Pesona PAUD, 1(672013167), 015. https://doi.org/https://doi.org/10.24036/1626

Fitri, R., \& Hazizah, N. (2019). Pelaksanaan Pengembangan Motorik Halus Anak pada Sentra Seni dan Kreativitas di TK. JFACE: Journal of Family, Adult, and Early Childhood Education, 1(2), 147-152. https://doi.org/10.5281/zenodo.2649345

Hardiyanti, Y., Husain, M. S., \& Nurabdiansyah, N. (2018). Perancangan Media Pengenalan Warna Untuk Anak Usia Dini. Jurnal Imajinasi, 2(2), 43. https://doi.org/10.26858/i.v2i2.9553 
Jumilah, Efastri, S. M., \& Fadillah, S. (2018). Upaya Meningkatkan Kreativitas Anak melalui Permainan Finger Painting Usia 5-6 Tahun di TK Harapan Bunda Pekanbaru. PAUD Lectura: Jurnal Pendidikan Anak Usia Dini, 2(1), 31-39. https://doi.org/DOI : https://doi.org/10.31849/paudlectura.v2i01.1989

Larasati, L. D., Kurniah, N., \& D., D. (2016). Peningkatan Kreativitas Dalam Kegiatan Mewarnai Dengan Menggunakan Metode Demonstrasi. Jurnal Ilmiah Potensia, 1(2), 62-66. https://doi.org/https://doi.org/10.33369/jip.1.2.62-66

Martinasari, K. S., Putra, I. K. A., \& Darsana, I. W. (2016). Penerapan Metode Pemberian Tugas Melalui Kegiatan Usab Abur untuk Mengingkatkan Keterampilan Motorik Halus pada Anak. E-Journal Pendidikan Anak Usia Dini Universitas Pendidikan Ganesh, 4(2). https://doi.org/DOI: http://dx.doi.org/10.23887/paud.v4i2.7844.

Miranda, D. (2016). Upaya Guru Dalam Mengembangkan Kreativitas Anak Usia Dini di Kota Pontianak. Jurnal of Prospective Learning, 1(1), 60-67.

Musfiroh, T., \& Tatminingsih, S. (2015). Bermain dan Permainan Anak. Jarkarta: Universitas Terbuka.

Nurhayati. (2012). Peningkatan Kreativitas Anak Usia Dini Dengan Bereksplorasi Melalui Koran Bekas Di Taman Kanak-Kanak Aisyiyah 2 Duri. Jurnal Pesona PAUD Vo.1 No.1, 1, 1-10. https://doi.org/https://doi.org/10.24036/1701

Pamadhi, H., \& Sukardi, E. (2013). Seni Keterampilan Anak. Jakarta: Universitas Terbuka.

Peny Husna, H., Gandamana, A., \& Farihah. (2017). Pengembangan Kreativitas Anak Usia Dini Dalam Keluarga. Jurnal Keluarga Sehat Sejahtera, 15(2), 46-56. https://doi.org/10.24114/jkss.v15i2.8774

Priyanto, A. (2014). Pengembangan Kreativitas Pada Anak Usia Dini Melalui Aktivitas Bermain. Jurnal Ilmiah Guru Caraka Olah Pikir Edukatif, O(2).

Putro, K. Z. (2016). Mengembangkan Kreativitas Anak Melalui Bermain. Aplikasia: Jurnal Aplikasi Ilmu-Ilmu Agama, 16(1), 19. https://doi.org/10.14421/aplikasia.v16i1.1170

Sukamti, E. R. dkk. (2010). Bermain dan Kreativitas sebagai Fondasi bagi Tumbuh Kembang Anak Usia Dini. FIK UNY: Yogyakarta.

Susanto, A. (2012). Perkembangan Anak Usia Dini. Jakarta: Kencana Prenada Media Group.

Wahyuti, F. S., Diana, \& Sutrisno. (2017). Penerapan Metode Demonstrasi Melalui Kegiatan Usab Abur Untuk Meningkatkan Kreativitas Anak di TK Ikal Dolog Pontianak Kota. Edukasi: Jurnal Ilmiah Pendidikan Anak Usia Dini, 5(1), 1-10. https://doi.org/doi: http://dx.doi.org/10.29406/jepaud.v5i1

Wibowo, D. V., \& Suyadi. (2020). Kegiatan KreativitasSeniWarna Anak Usia Dini Melalui Permainan Cat Air diMasa Pandemi. 4(1), 112-122. https://doi.org/10.31849/paudlectura.v

Yulida, y, \& Veryawan, V. (2018). Upaya Meningkatkan Kreativitas Seni Aank Melalui Kegiatan Teknik Kolase. Atfäluna: Journal of Islamic Early Childhood Education, 1(1), 19-23. https://doi.org/http://dx.doi.org/10.32505/atfaluna.v1i1.770 
Al-Athfaal: Jurnal Ilmiah Pendidikan Anak Usia Dini

Vol.3 No.2 (2020) 112-125

p-ISSN : 2622-5484

http://ejournal.radenintan.ac.id/index.php/al-athfaal

e-ISSN : 2622-5182

Desember 2020

Zaman, B., \& Hernawan, A. H. (2016). Media dan Sumber Belajar PAUD. Jakarta: Universitas Terbuka. 